\title{
Study of The Validity and Reliability of Nanotechnology Awareness Scale in Turkish Culture
}

\author{
Zeki Ipek (iD) 1, ${ }^{*}$ Ali Derya Atik (iD) 2 , Seref Tan (iD) 3 , Figen Erkoc (iD) \\ ${ }^{1}$ Republic of Turkey, Ministry of National Education, Antalya, Turkey \\ ${ }^{2}$ Kilis 7 Aralık University, Matematics and Science Education Department, Kilis Turkey \\ ${ }^{3}$ Gazi University, Department of Measurement and Evaluation in Education, Ankara, Turkey \\ ${ }^{4}$ Gazi University, Department of Biology Education, Ankara, Turkey
}

\begin{abstract}
ARTICLE HISTORY
Received: March 24, 2020

Revised: Sept. 13, 2020

Accepted: Oct. 22, 2020

KEYWORDS

Nanotechnology,

Nanotechnology awareness, Nanotechnology exposure,

Validity,

Reliability

Abstract: The aim of this study was to determine the validity and reliability of the Nanotechnology Awareness Scale (NAI) in Turkish culture. The study group consists of 624 biology, physics and chemistry teachers working in secondary schools in Antalya, Denizli, Burdur and Ankara. Exploratory Factor Analysis (EFA) and Confirmatory Factor Analysis (CFA) were conducted in order to determine its structural validity. Cronbach-alpha and stratified-alpha coefficient values were calculated for the reliability of the sub-dimensions and the whole of the scale, respectively. In EFA, Kaiser-Meyer-Olkin (KMO) value was found to be 0.92 and the Bartlett Test result $(91291=6519.27, p<.00)$ was found significant. In addition, in original scale, a two-factor structure was found. This two factors solution explains $59.192 \%$ of the total variance. In CFA, factor structure of the scale was tested for two-factor solution as it was designed. According to the findings, it was found that the scale, containing 14 items with two sub-dimensions, had sufficient goodness of fit indices such as $\chi 2 / \mathrm{sd}=1.344$, RMSEA $=0.07$, GFI $=$ $0.97, \mathrm{CFI}=0.97, \mathrm{NFI}=0.90$ and $\mathrm{AGFI}=0.83$. These goodness of fit indices shows that we have good model-data fit. The Stratified-alpha coefficient was found as 0.942 for the whole scale. Cronbach alpha coefficient was found as 0.935 and 0.805 for the awareness sub-dimension and exposure sub-dimension, respectively. As a result of the research, it was concluded that the Turkish version of the scale can be used as a valid and reliable measurement tool.
\end{abstract}

\section{INTRODUCTION}

Nanoscience and nanotechnology (NSNT) is a very rapidly changing field and defined as one of the six key enabling technologies (KETs) by the European Commission, including advanced manufacturing technologies; advanced materials and nano-technologies; life science (as a broader definition of industrial-biotechnology); micro and nano-electronics and photonics; artificial intelligence; security and connectivity (Jackman et al., 2016). All are related to digital technologies (e-skills). Nanotechnology is the driving force behind a new industrial revolution with both the private and public sectors constantly spend more in research, innovation and commercialization. The expected growth rates and size of the market for nanotechnology 
products is already comparable to the biotechnology sector (OECD, 2018). The initial nanoscale materials have been used in applications such as window glass, sunglasses, car bumpers and paints. Presently, the convergence of scientific disciplines (physics, biology, chemistry, electronics, engineering etc.) as a multidisciplinary field for wider scope and much diverse applications in materials manufacturing, computer chips, medical diagnosis and health care, energy, biotechnology, space exploration, security has introduced "NANO" to our daily lives and is expected to have a significant impact on economy and society, while generates great opportunities for cutting-edge research in science and for innovation in industrial production within the next decade. Furthermore, scientific and technology breakthroughs are expected in the long-term time scale. Nanotechnology increasingly takes the role of an enabling technology to biotechnology. The competitiveness of global industry depends on the effective use of new technologies and the knowledge, skills, competences and creativity of its workforce. Shortages, gaps and mismatches in high-tech skills negatively affect innovation, productivity growth, job creation and social cohesion. Public policies, education and training systems to react in time and funding programmes for high-tech skills development, to identify good practices and to make concrete recommendations for scaling up best practices and re-focusing funding programmes are necessary. (European Commission, 2019; OECD, 2018; Roco et al., 2011). Accordingly, scientists have raised concerns that the free particles smaller than one billionth of a meter as the basic building blocks of NBNT pose a potential new class of risk to health and the environment (Lauderwasser, 2005).

The motivation for continuous education and training and life-long-learning is the potential key for developing countries in the world NSNT market and industry workforce. Although NSNT is well established in academia and industry, the current generation of science teachers have insignificant exposure to NSNT, and few opportunities to understand the basic concepts (Andina et al., 2019; Hingant \& Albe, 2010; Pas et al., 2019; Winkelmann \& Bhushan, 2016). Since teachers are the force shaping students who will be the citizens of the future they need to be prepared for these developments in research, innovation and economy based on the new generation technologies (Jones et al., 2013; Laherto, 2010; Wansom et al., 2009).

Presently NSNT is not in neither the Primary School Science nor Secondary School Biology curricula. Nanotechnology topics are limited to $12^{\text {th }}$ grade physics and chemistry courses in secondary schools with two lecture hours (Ministry of National Education Turkey (MoNE), 2013, 2017). There is a similar situation in higher education undergraduate courses in Turkish universities which offer courses as electives only in engineering and science faculties of few universities with limited content. However, increasingly more universities have NSNT education in their graduate level programs; but resources in Turkish are very rare (Ijpek et. al., 2017). NSNT education is still a relatively new field. Therefore, Turkey also needs to adapt such policies and changes for NSNT education and research. In addition, there is a necessity, at the international level, to update nanotechnology topics in secondary level physics, chemistry and biology curricula to incorporate scientific developments (Roco \& Bainbridge, 2003). Having a good NSNT education at primary and secondary levels will be effective in the students' academic self-development, future career choices, citizen-science, and science communication (Karataş \& Ülker, 2014). The need for research to measure teachers' awareness, attitudes and knowledge about NSNT was the driver behind our research. Level of awareness of secondary level school biology, physics and chemistry teachers is evaluated using a cultural adaptation of the NAI (Nanotechnology Awareness Instrument) developed by Dyehouse et al. (2008) with validity and reliability to Turkish culture. Our results would contribute to planning for science teachers' training needs and draw attention of academia and private sector, research institutes to NSNT education to start in pre-higher education levels to promote student academic self-development, future career choices, citizen-science, and science communication for future. There is no measurement tool to measure Nanotechnology Awareness in Turkish Language. 
Therefore, the purpose of this article is to adapt NAI to Turkish language and to study the validity and reliability of this Turkish version obtained.

\section{METHOD}

Research model, study group, data analysis and cross-cultural adaptation of NAI instrument originally developed by Dyehouse et al. (2018) are presented in this section.

\subsection{Study Design}

Researchers use different methods for the translation, adaptation and cross-cultural validation of an original instrument and target culture by considering the differences between the original source and the target culture while maintaining equivalence of meaning. The process of translation, adaptation, and cross-cultural validation of an instrument for use on other cultures, languages, and countries requires careful planning and adaptation of comprehensive methodological approaches (Sousa \& Rojjanasrirat, 2011). The purpose of translation is to achieve equivalence between the instrument in the original language and the scale in the target language (Chapman \& Carter, 1979). Pilot testing of the pre-final version of the scale is used to be easily understood by the target population prior to psychometric testing (cognitive debriefing). Full psychometric testing of the pre-final version of the scale among individuals from the target population used to establish internal consistency reliability (or sensitivity and specificity), stability reliability, homogeneity, construct-related validity, criterion-related validity, factor structure and model fit of the instrument.

\subsection{Study Group}

The study group consisted of physics, chemistry, and biology teachers participate in distinct cities. The respondents who were participated in in-service training or a course from a faculty member on this subject or following scientific journals, documentaries, etc. were selected as far as possible. The interviews were conducted face to face, and the teachers were asked to write their own answers to the written documents. The respondents participated in the study voluntarily. The require ethical approval was taken from Gazi University Ethical Committee (Date/Number: 19.02.2016 / 81576613/605/1955049).

$46.2 \%(n=288)$ of the respondents were female and $53 \%(n=336)$ were male. The seniority in the profession distribution was: $1-5$ years $17.6 \%(n=110) ; 6-10$ years $13.9 \%(n=87) ; 11-15$ years $15.9 \%(\mathrm{n}=99)$; $16-20$ years $18.3 \%(\mathrm{n}=114) ; 21-25$ years $19.7 \%(\mathrm{n}=123) ; 26$ years and over $14.6 \%(\mathrm{n}=91)$. When the respondents' branches were examined, $30.6 \%(\mathrm{n}=191)$ was physics, $25.6 \%(\mathrm{n}=160)$ was chemistry, and $43.8 \%$ was biology. $26 \%(\mathrm{n}=162)$ of the respondents have Master's degree and $2.4 \%(n=15)$ have $\mathrm{PhD}$ degree. The respondents of $10.1 \%(\mathrm{n}=63)$ teacher worked in Science High School, 54.2\% $(n=338)$ in Anatolian High School, and 35.7\% $(n=223)$ Vocational High School. The cities where the respondents work were-Antalya (36.2\%), Denizli (34.8\%), Burdur (12.7\%), and Ankara (16.3\%) during 2015/2016 acedemic year.

\subsection{The Procedure of the Cross-cultural Validity and Reliability Testing}

The process of study is given below;

\section{a. Translation of the original instrument into the Turkish (forward translation or one-way translation):}

Permission to adapt NAI to Turkish culture and use was obtained via e-mail communication from Dr. Dyehouse (Learning Systems Institute, Florida State University, Tallahassee, FL, USA).

The original instrument NAI consists of two parts. Part A: Awareness (eight items), Exposure (six items), and Motivation (five items). The Awareness subscale aims to measure how aware respondents are of the impact and application of nanotechnology. The Exposure subscale 
measures the respondents' exposure and experiences with nanotechnology. The Motivation subscale contains five statements that describe types of related nanotechnology activities. Part B: Nano-Knowledge (eight items), Nanotechnology Uses and Equipment (seven items). The Knowledge subscale items included a correct answer and measures knowledge about nanotechnology facts. The second subscale provides information about how familiar respondents are with nanotechnology uses and equipment (Dyehouse et al., 2008). We used the subscales of Awareness and Exposure, with 14 items. Furthermore, İpek (2017) developed the additional third subscale with 10 items to measure knowledge about NSNT. These were reduced to five items after opinions of a field, an education and a measurement and assessment experts were obtained, and the final version was elaborated. This knowledge subscale aims to increase reliability of the data collected from the instrument in awareness subscale by improving sincerity of the responses. In subscale $\mathrm{C}$ (knowledge), respondents answer some questions related to awareness subscale. These questions are presented in the form of fill in the blank and "open-ended" questions. Responses of teachers to these questions are assessed to determine their real knowledge level of NSNT.

The NAI in the original language is forward translated to Turkish by two independent translators. The translators (two academicians and one language editor) speak English fluently and have in-depth experience in the culture of the source. And, translators have distinct backgrounds. The first translator is the physics professor who studies in the field of nanotechnology. So, he has knowledge about nanotechnology terminology, and the subject area of the construct of the instrument. The second translator is familiar with assessment and evaluation in education. To achieve equivalence between the instrument in English and the instrument in the Turkish, well-qualified translators were chosen. The items were first translated by two with specialty in translation (Version 1 translation a: V1a and Version 1 translation b: V1b).

\section{b. Comparison of the two translated versions of the instrument}

The third bilingual independent expert in grammar and language compared the items of the two forward translated versions (V1a and V1b) of the instrument (V1a and V1b) and both the V1a and the V1b with the original version of the instrument (NAI) words, sentences and meanings.

\section{c. Blind back-ward (double) translation and comparation of the two back-translated versions of the instrument}

The comparison of the two translated versions of the instrument translated back into English by four other independent another translator that had never seen the original version of the instrument with the same qualifications and characteristics. These four experts had undergraduate degrees in English language and literature. They produced two back-translated versions of the instrument. This step allowed for clarification of words and sentences used in translations. The experts compared the translations with the items of the original instrument NAI regarding format, the grammatical structure of the sentences, the similarity in meaning, and relevance. The two translated texts were merged, and experts agreed that it was consistent with the original instrument NAI. A native English speaker expert, who also has good command of Turkish reviewed the original and translated versions of the instrument and confirmed consistency of the Turkish version with the original. The equivalence of the items in the scale in terms of semantic, idiomatic, experiential, and conceptual aspects were reviewed by two experts in the field. Some items were amended based on opinions of these experts. Thus, pilot testing of the pre-final version (PF-V) of the instrument was prepared.

\section{d. Pilot testing of the pre-final version of the instrument}

The participants whose language is Turkish tested the PF-V of the instrument evaluated the items of the instrument for clarity. A sample size of 10-40 individuals is recommended for pilot 
testing the instrument (Beaton et al., 2000). Participants response format or any item of the instrument as unclear asked to provide suggestions as to how to write the statements to make the language clearer. The sample is 20 students, seniors of English Teacher Program of Faculty of Education, Akdeniz University were given the Turkish and English versions with a one-week interval and to confirm consistence/agreement and no problems were reported in comprehension of the items. The final version (FV) was termed Nanoscience and Nanotechnology Awareness Scale (NSTAS).

\section{e. Testing the FV of the translated instrument in a sample of the target population}

This last step used to establish the initial full psychometric properties of the newly translated, adapted and cross-validated instrument with a sample of the target population of interest. The sample depends on the types psychometric approaches that will be used. In general, it is highly recommended to use at least 10 subjects per item of the instrument scale and item analysis and exploratory factor analysis. If there is a plan to use confirmatory factor analysis to test the factor structure of the instrument, the recommendation per rule of thumb is approximately $300-500$ subjects per item of the instrument (Tabachnick \& Fidell, 2001). To testing the NSTAS in a sample of the target population was participated 624 teachers form distinct branches (physics, chemistry, and biology) and cities. Sample size significance for factor analysis was satisfactory.

\subsection{Data Analysis}

For the FV, factorial structure of the instrument, structural validity, reliability of scale scores and item discrimination indexes were assessed. EFA and CFA were carried out for construct validity of the scale. Reliability of the subscales were calculated using Cronbach's alpha and stratified alpha coefficient for overall reliability of the scale.

\section{RESULT / FINDINGS}

\subsection{Results of Exploratory Factor Analysis}

Kaiser-Meyer-Olkin measure of sampling adequacy (KMO) statistic indicating the proportion of variance in our variables which might be caused by underlying factors for applicability of items in Nanoscience and Nanotechnology Awareness Scale (NSTAS) was .92; values around .90 indicating that factor analysis will be useful (Schermelleh-Engel et al., 2003; Young \& Pearce, 2013). Bartlett's Test of Sphericity was found to be significant $\left(\chi^{2}{ }_{91}=6519.27, p<.00\right)$; showing that correlation matrix is not an identity matrix, indicating our variables to be related and therefore suitable for dimension reduction for creating factors.

Exploratory factor analysis was the first procedure applied to our data set to examine the factorial structure. Since theoretically only two factors were in the original Instrument, we limited factors to two in exploratory factor analysis, and in this case, principle axis factoring method was used as factor extraction method (Tan, 1999). The factor loadings were found to be above .50 each, indicating strong loadings (Seçer, 2013).

Both factors have Eigenvalues above 1 (Table 1), the items gather under the two factors and explain $59.191 \%$ of the total scale variance (Zwick \& Velicer, 1986). Our analysis shows that two factor analysis is appropriate since explained total variations by two factors is very close to $60 \%$ (Bektaş, 2015; Deniz et al., 2013). 
Table 1. Total Variances Explained for NSTAS

\begin{tabular}{cccc}
\hline Items & & Total Variances Explained & \\
\cline { 2 - 4 } & Eigen Value & Variance $(\%)$ & Total (\%) \\
\hline 1 & 7.019 & 50.138 & 50.138 \\
2 & 1.267 & 9.053 & 59.191 \\
\hline
\end{tabular}

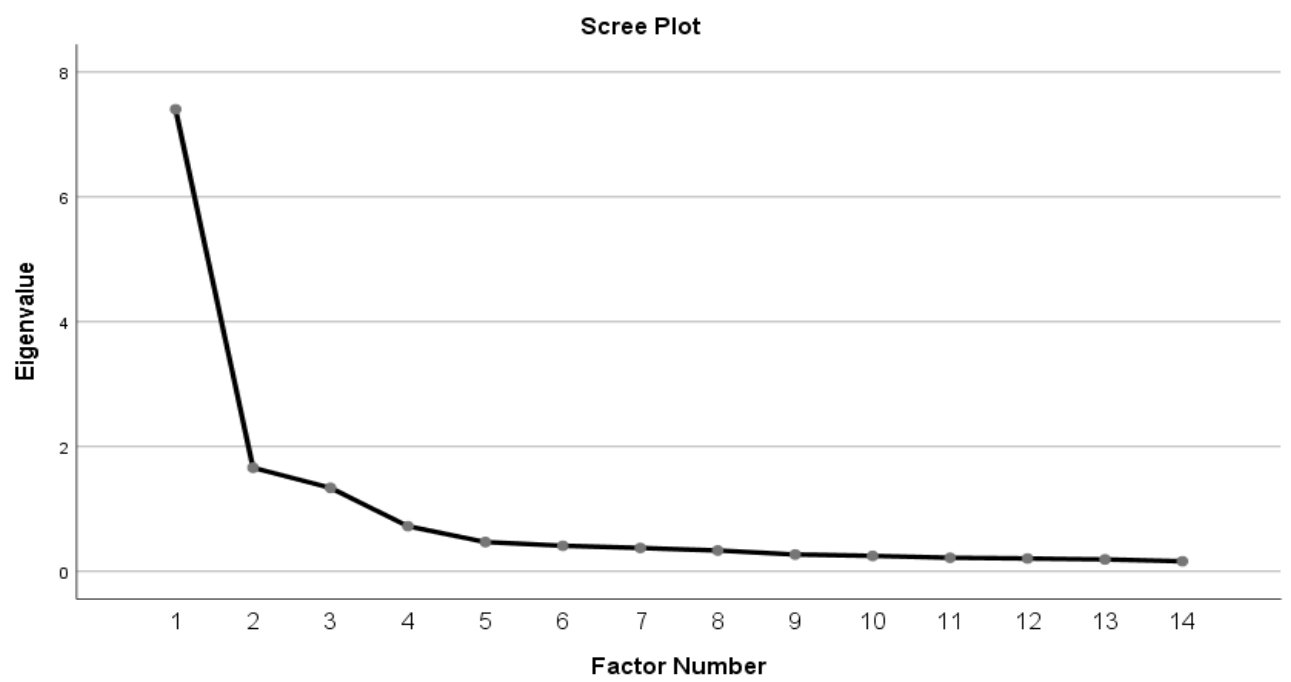

Figure 1. Scree plot of the eigenvalues of the factors for NSTAS.

The scree plot graph based on Eigenvalues of the factors is depicted in Figure 1, this enables us to give a final decision on number of factors (Henson \& Roberts, 2006). The slope of the scree plot is in the same direction after factor 2 (Figure 1), verifying the number of factors as two (Thompson, 2004; Zwick \& Velicer, 1986). The first factor is named "Awareness" and the second "Exposure" keeping the structure of the original Instrument.

Table 2 depicts results of the direct oblimin method where distribution of the items to factors are investigated since the factors are correlated this oblique rotation employed (Osborne \& Costello, 2005).

Table 2. Distribution of Factor Loadings by Factors of NSTAS Items

\begin{tabular}{lll}
\hline Items & \multicolumn{3}{c}{ Factors } \\
\cline { 2 - 3 } & \multicolumn{1}{c}{2} \\
\hline $\mathrm{A}_{1}$ & .88 & \\
$\mathrm{~A}_{2}$ & .87 & \\
$\mathrm{~A}_{3}$ & .76 & \\
$\mathrm{~A}_{4}$ & .89 & \\
$\mathrm{~A}_{5}$ & .86 & \\
$\mathrm{~A}_{6}$ & .56 & \\
$\mathrm{~A}_{7}$ & .53 & .39 \\
$\mathrm{~A}_{8}$ & .75 & .49 \\
$\mathrm{~B}_{1}$ & & .52 \\
$\mathrm{~B}_{2}$ & & .82 \\
$\mathrm{~B}_{3}$ & & .82 \\
$\mathrm{~B}_{4}$ & & .73 \\
$\mathrm{~B}_{5}$ & & \\
$\mathrm{~B}_{6}$ & & \\
\hline
\end{tabular}


Table 2 shows cluster of eight items in the Awareness factor, and six items in the Exposure factor. Factor loadings of the items in the first factor ranged between .52 to .87 , the second factor had .39 to .82 . There is a positive but moderate correlation between the first and second factors $(\mathrm{r}=.58, p<.05)$. These results are the same as the original factorial structure of NAI (The two factors of NAI were moderately correlated at 0.52 and NanoAwareness and NanoExposure items, loaded onto factor 2. Pattern coefficients for the second factor ranged from 0.26 to 0.85 ) (Dyehouse et al., 2008).

\subsection{Reliability and Validity of NSTAS Scores}

Awareness subscale items have corrected total score correlation coefficients of .69 to .82 in Table 3.

Table 3. Corrected Item Total Score Correlations for Awareness Sub-scale Items of NSTAS

\begin{tabular}{ccc}
\hline Items & Corrected Item Total Correlation & Cronbach's Alpha If Item Deleted \\
\hline $\mathrm{A}_{1}$ & .78 & .93 \\
$\mathrm{~A}_{2}$ & .79 & .93 \\
$\mathrm{~A}_{3}$ & .77 & .93 \\
$\mathrm{~A}_{4}$ & .82 & .92 \\
$\mathrm{~A}_{5}$ & .82 & .92 \\
$\mathrm{~A}_{6}$ & .72 & .93 \\
$\mathrm{~A}_{7}$ & .69 & .93 \\
$\mathrm{~A}_{8}$ & .78 & .93 \\
\hline
\end{tabular}

Exposure subscale items have corrected total score correlation coefficients of .54 to .71 in Table 4. We conclude that total corrected item correlations are satisfactory (very high). In other words, all items in the sub-scales have very high item discrimination power.

Table 4. Corrected Item Total Score Correlations of B (Exposure) Sub-Dimension Items of NSTAS

\begin{tabular}{ccc}
\hline Items & Corrected Item Total Correlation & Cronbach's Alpha If Item Deleted \\
\hline $\mathrm{B}_{1}$ & .54 & .84 \\
$\mathrm{~B}_{2}$ & .71 & .81 \\
$\mathrm{~B}_{3}$ & .69 & .82 \\
$\mathrm{~B}_{4}$ & .69 & .81 \\
$\mathrm{~B}_{5}$ & .64 & .82 \\
$\mathrm{~B}_{6}$ & .54 & .84 \\
\hline
\end{tabular}

Table 5. Internal Consistency Coefficients for NSTAS

\begin{tabular}{cccc}
\hline Sub-dimension & Variance & $\begin{array}{c}\text { Cronbach's alpha } \\
\text { Coefficient }\end{array}$ & $\begin{array}{c}\text { Stratified Cronbach's alpha } \\
\text { Coefficient }\end{array}$ \\
\hline A: Awareness & 67.66 & 0.93 & - \\
\hline B: Exposure & 28.98 & 0.85 & - \\
\hline NSTAS & 152.09 & - & 0.94 \\
\hline
\end{tabular}

As it given in Table 5, stratified Cronbach's alpha coefficient (Feldt \& Qualls, 1996) of NSTAS (overall reliability) was found as .94. Calculation of the stratified Cronbach's alpha coefficient is the preferred method of reporting reliability estimates when multifactors are concerned (Tan, 2009). Cronbach's alpha coefficients were found to be .93 for Awareness and .85 for Exposure subscales, therefore the sub-scales and NSTAS have very high reliability levels. 


\subsection{Results of Confirmatory Factor Analysis}

CFA was carried out to decide whether the two factors model is confirmed or not. Goodness of fit indices are depicted in Table $6: \chi 2 / \mathrm{df}=1.344$, RMSEA $=.07$, GFI $=.97, \mathrm{CFI}=.97, \mathrm{NFI}=$ .90 and AGFI $=.83$, all findings are at good and excellent level $(\mathrm{Hu} \&$ Bentler, 1999; Schermelleh Engel et al., 2003; Kline, 2005).

Table 6. Comparison of Standard Goodness of Fit Measures and Research Results

\begin{tabular}{cccc}
\hline $\begin{array}{c}\text { Goodness of Fit } \\
\text { Measure }\end{array}$ & Good Fit & Acceptable Fit & $\begin{array}{c}\text { Goodness of fit Values } \\
\text { Obtained in the Research }\end{array}$ \\
\hline$\chi 2 / \mathrm{df}$ & $0 \leq \chi 2 / \mathrm{df} \leq 2$ & $2 \leq \chi 2 / \mathrm{df} \leq 3$ & 1.344 \\
\hline RMSEA & $0 \leq \mathrm{RMSEA} \leq 0.05$ & $0.05 \leq \mathrm{RMSEA} \leq 0.08$ & 0.07 \\
\hline NFI & $0.95 \leq \mathrm{NFI} \leq 1.00$ & $0.90 \leq \mathrm{NFI} \leq 0.95$ & 0.90 \\
\hline CFI & $0.97 \leq \mathrm{CFI} \leq 1.00$ & $0.95 \leq \mathrm{CFI} \leq 0.97$ & 0.97 \\
\hline GFI & $0.95 \leq \mathrm{GFI} \leq 1.00$ & $0.90 \leq \mathrm{GFI} \leq 0.95$ & 0.97 \\
\hline AGFI & $0.90 \leq \mathrm{AGFI} \leq 1.00$ & $0.85 \leq \mathrm{AGFI} \leq 0.90$ & 0.83 \\
\hline
\end{tabular}

AGFI value is .83 , below the acceptable limit of .85 . However, since it is close to the acceptable limit value of .85 and $\chi 2 / \mathrm{df}$ value calculated as 1.344 , smaller than 3 , when we consider the values given in Table 6, we conclude that the scale has good fit indices (Schermelleh-Engel et al., 2003). The results confirm the measurement model of NSTAS, given in Figure 2.

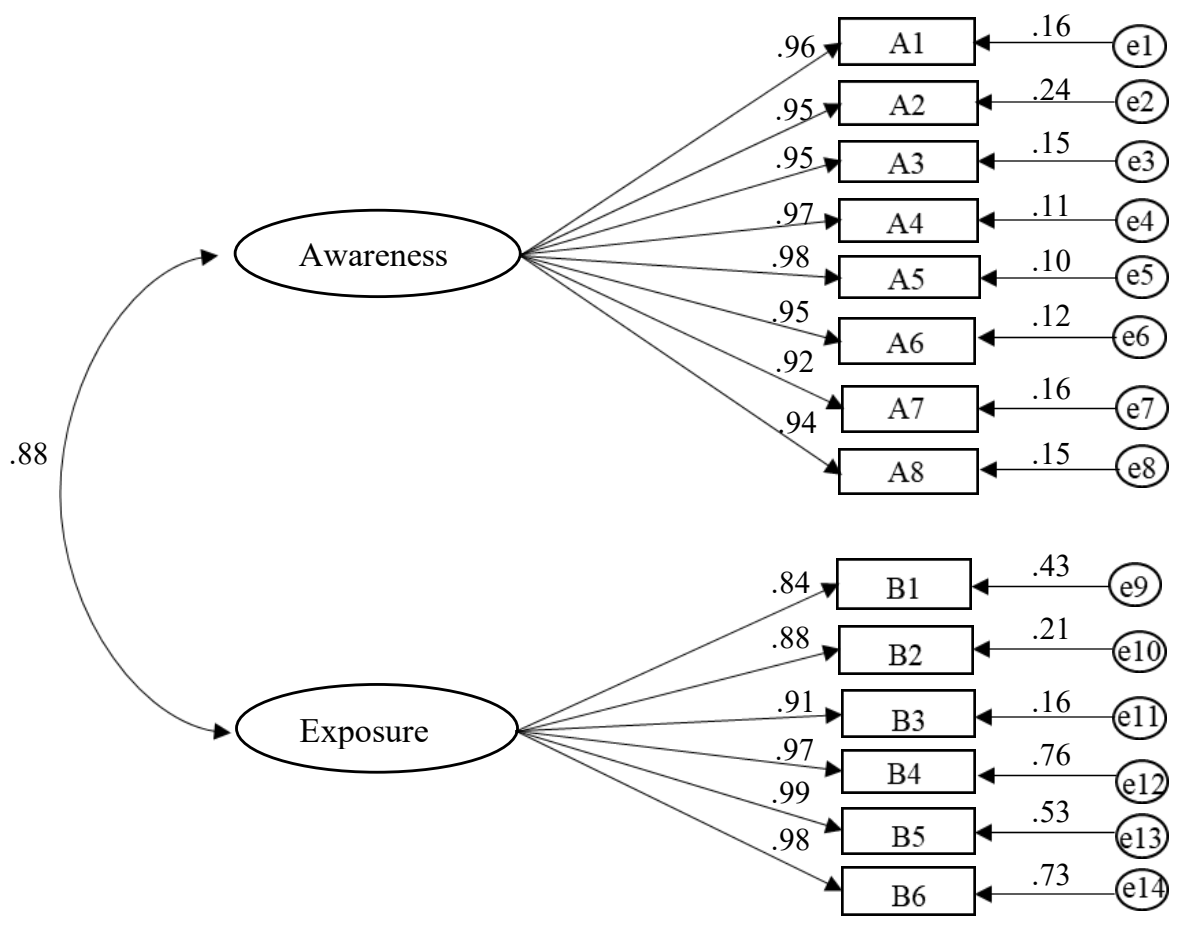

Figure 2. Confirmatory Factor Analysis Structural Modeling of NSTAS to Awareness (A) and Exposure (B) Sub-dimensions

As it seen in Figure 2, the Awareness and Exposure factors (latent variables) correlated with each other. Each observed variable is loaded on the related factor and all factor loadings and factor correlations in the model were found to be significant. The value of .88 depicting correlation between the two latent variables confirms that Awareness and Exposure latent variables are correlated. Standardized coefficients of the measurement model provides view 
that each item (observed variable) is a good representative of its' latent variable (Çelik \& Y1lmaz, 2013). In conclusion, the results of CFA show that this measurement model confirms the structural validity of the NSTAS scores. So, the measurement of applying the NSTAS to 624 teachers for cross-cultural adaptation to Turkish are statistically proven to be valid and reliable.

\section{DISCUSSION and CONCLUSION}

The rapid development of nanotechnology and its impact on the economy has led to the focus on nanotechnology education. Nanotechnology is a relatively new field, and as such is not yet widely understood by the society. Because it is difficult to train qualified manpower of the mentioned size easily and in a short time (Laherto, 2010). Many educational interventions are being implemented to address workforce issues in the field of nanotechnology. When the literature is reviewed, it is seen that nanotechnology education has started to take its place at the secondary education level in many developed countries. According to the new researches, nanotechnology education must start earlier grades such as middle and primary schools. Many countries, several nanotechnology training materials for the K-12 level have already been developed. Although the researches and planning the activities on NST education started from the primary school in USA, Europe and developed countries, NST educational researches are limited and curricular planning studies are not sufficient in Turkey. Nanotechnology is not mentioned at all grade levels in the curricula of science courses in primary schools and Biology courses in secondary schools, currently. The public and the next generations are informed about nanotechnology are crucial.

To increase the awareness of NST, education and training activities from primary education to university level should be organized in a conscious and programmed manner. The most important and first step in this process is to determine the current situation. To determine the awareness and knowledge levels of biology, physics, and chemistry teachers are working in secondary schools is a critical and important beginning to show the current situation. However, there is no Turkish instrument to assess the teachers/students' awareness of and exposure to nanotechnology. To address this need, the study of the validity and reliability of NAI in Turkish culture was conducted. This research is expected to be a source for researchers who will work on NST in Turkey. The research has been conducted considering the following limitations: The research calendar is limited to the 2015/2016 academic year. The research is limited to 624 biology, physics and chemistry teachers working in secondary education institutions located in the city center of Antalya, Ankara, Denizli and Burdur. The content of the research is limited to the awareness of teachers about the NSTAS subject, its teaching in secondary education, and the NST Awareness Scale. Research is limited with the resources available.

When developing the original instrument NAI, an explanatory factor analysis (EFA) for the Awareness, Motivation, and Exposure subscales was conducted to determine what underlying constructs were being measured. A principal factors analysis with a promax rotation (power $=3$ ) was used. Originally, five factors were retained. However, only four variables loaded onto the fifth factor. The scree plot revealed a levelling off after three factors. So a 3-factor solution was obtained. The factor solution indicated that Motivation can be considered a separate construct from Awareness and Exposure, although the constructs are moderately related. Awareness and Exposure subscales are similar enough to be considered a single construct. Because being aware of nanotechnology probably means that one has also been exposed to nanotechnology (Dyehouse et al., 2008).

Firstly, EFA applied in this study that was investigated the validity and reliability of NSTAS in Turkish culture. As a result of the eigenvalue, scree plot and explained total variance proportion examinations, it was determined that the number of scale factors was two as it was in the 
original scale and these two factors explained $59.19 \%$ of the total variance of the data. Also, the items have high factor loadings with related factor in the scale. These factor loading values and the CFA results show that the adapted instrument provides structural validity in Turkish culture.

The high "corrected item-total score correlations" for items in both sub-dimensions of NSTAS indicate that the item discrimination indexes are very high. Also, as in the original scale, moderate positive correlation $(r=.58 p<.05)$ between the awareness and exposure factors of NSTAS is another proof that compliance with the original scale structure is achieved.

The original instrument's (NAI) internal consistency Cronbach's alpha coefficient values were calculated for the Awareness scale was 0.91 and for the Exposure scale was .82. These coefficients showed a satisfactory level of internal consistency reliability (Dyehouse et al., 2008). The stratified alpha coefficient (.94) for the reliability of the NSTAS scores, Cronbachalpha coefficient for the awareness (.93) sub-scale scores and Cronbach-alpha coefficient for the exposure (.85) sub-scale scores showed that the adapted scale was highly reliable (Özdamar, 1999). For this reason, the Turkish version of the scale, composed of 14 items, gives valid and reliable results.

Furthermore, the model fit indices were tested with CFA and model goodness of fit indices were found to be good and excellent (see Table 6) (Schermelleh Engel et al., 2003). During the data collection process and the interviews with teachers, the participants stated that the newly developed knowledge sub-scale (C) section by the authors was a very effective approach to increase the reliability of the scale scores. In the scale development to measure especially affective domain, it is considered to be useful to use such sub-scale (C) that will verify the data obtained to increase the reliability of the scale or sub-scale scores.

As a result of the validity and reliability findings, the adopted scale can be used to determine the nanoscience and nanotechnology awareness of the secondary school biology, chemistry and physics teachers in Turkey.

The practical implication of this instrument may be able to determine the teachers and students' awareness of and exposure to nanotechnology. And it may be able to use to gather information about whether a program is effective for increasing their awareness and knowledge. Knowing the degree to which programs increase teachers/students' awareness, knowledge, and motivation will also aid in making curricular design decisions. Nanotechnology as a field of study or career provides opportunities for the next generation. This instrument may also be a valuable tool for students to draw attention nanotechnology as a field of study and carrier.

\section{Acknowledgements}

Preliminary results of this work have been presented in C-MEEP $20186^{\text {th }}$ International Congress on Measurement and Evaluation in Education and Psychology, September 5-8, 2018, Prizren, Kosovo.

\section{Declaration of Conflicting Interests and Ethics}

The authors declare no conflict of interest. This research study complies with research publishing ethics. The scientific and legal responsibility for manuscripts published in IJATE belongs to the author(s).

\section{ORCID}

Zeki İpek (iD https://orcid.org/0000-0002-8097-5849

Ali Derya Atik (D) https://orcid.org/0000-0002-5841-6004

Şeref Tan (D) https://orcid.org/0000- 0002-9892-3369

Figen Erkoç (id https://orcid.org/0000-0003-0658- 2243 


\section{REFERENCES}

Andina, R. E., Rahmawati, Y. \& Budi, S. (2019). Improved learning designs for shaping Indonesia's future science teachers applied in a nanoscience project. Issues in Educational Research, 29(4), 997-1015. http://www.iier.org.au/iier29/andina.pdf

Bektaş, H. (2015). Factor analysis for binary variables: An application on the quality of working life. Doctoral dissertation, İstanbul University, İstanbul, Turkey. https://tez.yok.gov.tr/UlusalTezMerkezi/tezSorguSonucYeni.jsp

Beaton, D. E., Bombardier, C., Guillemin, F. \& Ferraz, M. B. (2000). Guidelines for the process of cross-cultural adaptation of self-report measures. Spine, 25(24), 3186-3191.

Chapman, D. W. \& Carter, J. F. (1979) Translation procedures for the cross-cultural use of measurement instruments. Educational Evaluation and Policy Analysis, 1(3), 71-76. https://doi.org/10.3102/01623737001003071

Costello, A. B.\& Osborne, J. W. (2005). Best Practices in Exploratory Factor Analysis: Four Recommendations for Getting the Most from Your Analysis. Practical Assessment, Research \& Evaluation, 10(7), 1-9.

Çelik, H. E., \& Yılmaz, V. (2013). Yapısal eşitlik modellemesi: temel kavramlar, uygulamalar, programlama (2nd ed.). An1 Yayınc1lik.

Deniz, M. E., Özer, E., \& Işık, E. (2013). Duygusal zekâ özelliği ölçeği-kısa formu: Geçerlik ve güvenirlik çalışması [Trait Emotional Intelligence Questionnaire-Short Form: Validity and reliability studies]. Education and Science, 38(169), 407-419.

Dyehouse, M. A., Diefes-Dux, H. A., Bennett, D. E., Imbrie, Æ P. K. (2008). Development of an instrument to measure undergraduates' nanotechnology awareness, exposure, motivation and knowledge. J Sci Educ Technol.. 17, 500-510.

European Commission (2019). Skills for Industry. High-Tech Skills: Scaling up best practices and re-focusing funding programmes and incentives, Final Report. Executive Agency for Small and Medium-sized Enterprises (EASME), EASME/COSME/2018/016, 2019. Luxembourg: Publications Office of the European Union, 2019. PDF ISBN 978-92-9202548-9. https://doi.org/10.2826/024306 EA-01-19-571-EN-N

Hingant, B. \& Albe, V. (2010). Nanosciences and nanotechnologies learning and teaching in secondary education: A review of literature. Studies in Science Education, 46(2), 121 152. https://doi.org/10.1080/03057267.2010.504543

Feldt, L. S., \& Qualls, A. L. (1996). Bias in coefficient alpha arising from heterogeneity of test content. Applied Measurement in Education, 9(3), 277-286.

Henson, R. K. \& Roberts, J. K. (2006). Use of exploratory factor analysis in published research: common errors and some comment on improved practice. Educational and Psychological Measurement, 66(3), 393-416.

Hu, L. \& Bentler, P. (1999). Cutoff criteria for fit indices in covariance structure analysis: conventional criteria versus new alternatives. Structural Equation Modeling, 6, 1-55.

İpek, Z. (2017). Research on awareness levels of physics, chemistry, and biology teachers about nanoscience and nanotechnology. Doctoral Dissertation, Gazi University, Ankara. https://tez.yok.gov.tr/UlusalTezMerkezi/tezSorguSonucYeni.jsp

İpek, Z., Atik, A. D., Tan, Ş. \& Erkoç, F. (2020). Awareness, exposure, and knowledge levels of science teachers about nanoscience and nanotechnology. Issues in Educational Research, 30(1), 134-155. http://www.iier.org.au/iier30/ipek.pdf

Jackman, J. A., Cho, D. J., Lee, J., Chen, J. M., Besenbacher, F., Bonnell, D. A., ... Cho, N. J. (2016). Nanotechnology education for the global world: Training the leaders of tomorrow. ACSNano, 10, 5595-5599. https://doi.org/10.1021/acsnano.6b03872

Jones, M. G., Blonder, R., Gardner, G. E., Albe, V., Falvo, M., \& Chevrier, J. (2013). Nanotechnology and Nanoscale Science: Educational Challenges. International Journal of Science Education, 35(9), 1490-1512. 
Kalaycı, N. (2008). Yükseköğretimde uygulanan toplam kalite sürecinde göz ardı edilen unsurlardan "TKY merkezi" ve "eğitim programları". Tekışık.

Karataş, F. Ö., \& Ülker, N. (2014). Undergraduate chemistry students' understanding level of nano-science and nano-technology. Journal of Turkish Science Education, 11(3), 103118. https://doi.org/10.12973/tused.10121a

Kline, R. B. (2005). Principles and practice of structural equation modeling (second edition). Guilford Publications, Inc.

Laherto, A. (2010). An Analysis of the Educational Significance of Nanoscience and Nanotechnology in Scientific and Technological Literacy. Science Education International, 21(3), 160-175.

MoNE. Talim ve Terbiye Kurulu Başkanlığı (2013). Illkögretim Kurumlar (İlkokullar ve Ortaokullar) Fen Bilimleri Dersi (3, 4, 5, 6, 7 ve 8. Sinıflar) Öğretim Programı. Doc Player. https://docplayer.biz.tr/1747250-Fen-bilimleri-dersi-3-4-5-6-7-ve-8-siniflar.html

MoNE. Talim ve Terbiye Kurulu Başkanlığı (2018). Ortaöğretim Biyoloji, Fizik ve Kimya Dersi (9, 10, 11 ve 12. Sinıflar) Öğretim Programı. http://mufredat.meb.gov.tr/Programl ar.aspx

Lauterwasser, C. (Ed.) (2005). "Small sizes that matter: Opportunities and risks of Nanotechnologies", Report in co-operation with the OECD International Futures Programme. http://www.oecd.org/dataoecd/32/1/44108334.pdf

OECD (2018). Report on statistics and indicators of biotechnology and nanotechnology. OECD Science, Technology and Industry Working Papers 2018/06. Paris, France. https://dx.doi.org/10.1787/3c70afa7-en

Özdamar, K. (1999). Paket programlar ile istatistiksel veri analizi. Kaan.

Pas, M., Vogrinc, J., Raspor, P., Knezevic, N. U. \& Zajc, J. C. (2019). Biotechnology learning in Slovenian upper-secondary education: Gaining knowledge and forming attitudes. Research in Science \& Technological Education, 37(1), 110-125. https://doi.org/10.108 $\underline{0 / 02635143.2018 .1491473}$

Roco, M. C. \& Bainbridge, W. (2003). Societal implications of nanoscience and nanotechnology. Kluwer.

Roco, M. C., Mirkin, C. A. \& Hersam, M. C. (2011). Nanotechnology research directions for societal needs in 2020: Summary of international study. Journal of Nanoparticle Research, 13(3), 897-919. https://doi.org/10.1007/s11051-011-0275-5

Schermelleh-Engel, K., Moosbrugger, H. \& Müler, H. (2003). "Evaluating the Fit of Structural Equation Models: Tests of Significance and Descriptive Goodness-of-Fit Measures". Methods of Psychological Research Online, 8(2), 23-74. http://citeseerx.ist.psu.edu/vie wdoc/download?doi=10.1.1.509.4258\&rep=rep1\&type $=$ pdf

Seçer, İ. (2013). SPSS ve LISREL ile pratik veri analizi. An1.

Sousa, V.D. \& Rojjanasrirat, W. (2011). Translation, adaptation and validation of instruments or scales for use in cross-cultural health care research: a clear and user-friendly guideline. International Journal of Evaluation in Clinical Practice, 17, 268-274. https://doi.org/10 $.1111 / \mathrm{j} .1365-2753.2010 .01434 . \mathrm{x}$

Tabachnick, B. G. \& Fidell, L. S. (2001) Using multivariate statistics (4th edn.). Allyn \& Bacon.

Tan, Ş. (1999). Psikolojik Test Geliştirmede Faktör Analizinin Kullanımı. Çağdaş Eğitim, 255, 32-38.

Tan, Ş. (2009). Misuses of KR-20 and Cronbach's alpha reliability coefficients. TED Education and Science, 34(152), 101-112.

Tan, Ş. (2015). Uygulamal temel istatistik-1. Ankara: Pegem Akademi.

Thompson, B. (2004). Exploratory and confirmatory factor analysis: understanding concepts and applications. American Psychological Association.

Turgut, M. F. \& Baykul, Y. (1992). Ölçekleme teknikleri. Ankara: ÖSYM Yayınları. 
Ural, A. \& Kılıç, İ. (2005). Bilimsel araştırma süreci ve SPSS ile veri analizi. Ankara: Detay Yayıncilık.

Wansom, S., Mason, T. O., Hersam, M. C., Drane, D., Light, G., Cormia, R., Stevens, S., Bodner, G. M. (2009). A Rubric for Post-Secondary Degree Programs in Nanoscience and Nanotechnology. International Journal of Engineering Education, 25(3), 615-627.

Winkelmann, K. \& Bhushan, B. (Eds.) (2016). Global perspectives of nanoscience and engineering education. Science Policy Reports. Springer. https://link.springer.com/book 10.1007\%2F978-3-319-31833-2

Young, A. G., \& Pearce, S. (2013). A beginner's guide to factor analysis: focusing on exploratory factor analysis. Tutorials in Quantitative Methods for Psychology, 9(2), 7994.

Zwick, W.R. \& Velicer, W. F. (1986). Factor Influencing Five Rules for Determining the Number of Components to Retain. Psychological Bulletin, 99, 432-442. 


\section{APPENDIX}

\section{Nanotechnology Awareness Instrument (NAI, Turkish version)}

\section{Sayın Katılımcl:}

Aşă̆ldaki farkındalık ölçeğinde Nanobilim ve Nanoteknoloji (NBT) ile ilgili ifadeler bulunmaktadır. Her ifadenin karşısında beş (5) cevap seçeneği vardır. Her cümleyi okuduktan sonra cümledeki ifadeye ne düzeyde katıllyorsanız, o cevap seçeneğini (X) işaretleyiniz. Cevap seçenekleri arasında doğru ya da yanlış cevap bulunmamaktadır. Lütfen hiçbir ifadeyi boș bırakmayınız. Katkılarınız için teșekkürler.

Farkındalık ölçeğini cevaplamadan önce aşă̆ıdaki kişisel bilgilerinizi doldurmanızı rica ederiz.

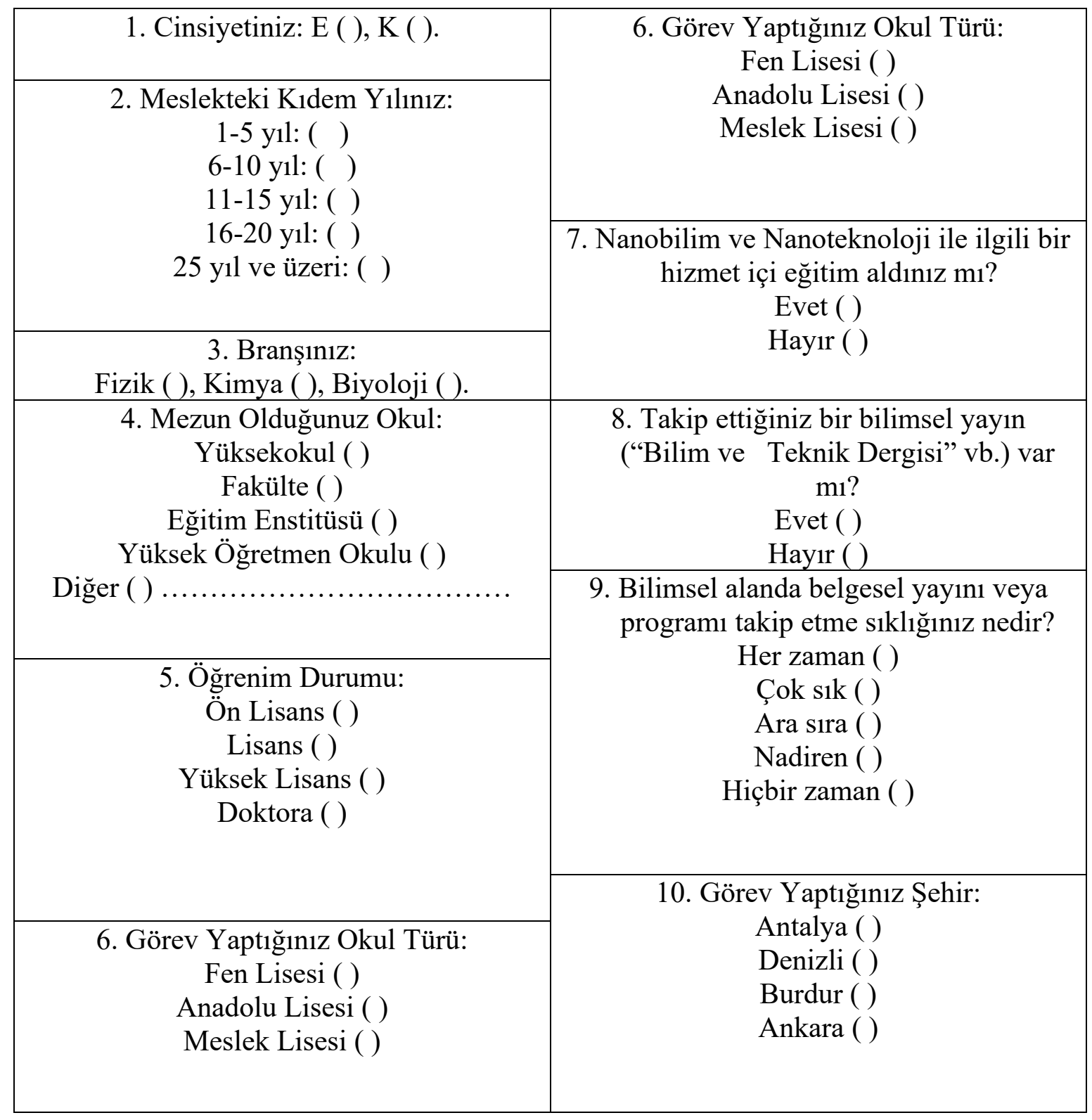


A. Aşağıdaki ölçeği kullanarak, ölçekte yer alan ifadelere katılım düzeyinizi her bir madde için lütfen belirtiniz.

\begin{tabular}{|c|c|c|c|c|c|}
\hline Nanobilim ve Nanoteknoloji Farkındalık Ölçeği & 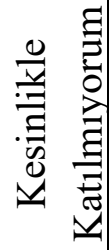 & 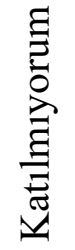 & 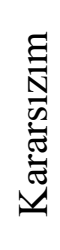 & 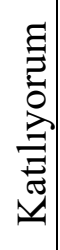 & 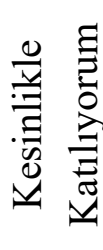 \\
\hline 1. Nanoölçek boyutunda bir nesne adı söyleyebilirim. & & & & & \\
\hline $\begin{array}{l}\text { 2. Nanoteknolojinin hayatımı doğrudan etkileyen bir } \\
\text { yöntemini söyleyebilirim. }\end{array}$ & & & & & \\
\hline $\begin{array}{l}\text { 3. Bugünlerde nanoteknoloji araştırması yürüten bir çalışma } \\
\text { alanı ismi söyleyebilirim. }\end{array}$ & & & & & \\
\hline $\begin{array}{l}\text { 4. Nanoteknolojinin topluma/insanlığa faydalı olabilecek bir } \\
\text { yöntemini tanımlayabilirim. }\end{array}$ & & & & & \\
\hline 5. Bir nanoteknoloji uygulamasının adını söyleyebilirim. & & & & & \\
\hline $\begin{array}{l}\text { 6. Nanoölçekte nesneler üretmek için kullanılan bir yöntemi } \\
\text { tanımlayabilirim. }\end{array}$ & & & & & \\
\hline $\begin{array}{l}\text { 7. Nanoölçekte ölçüm yapmakta kullanılan bir araç ismi } \\
\text { söyleyebilirim. }\end{array}$ & & & & & \\
\hline $\begin{array}{l}\text { 8. Gelecekte nanoteknolojinin hayatımı doğrudan } \\
\text { etkileyebilecek bir yöntemini söyleyebilirim. }\end{array}$ & & & & & \\
\hline
\end{tabular}

B. Aşağıdaki ölçeği kullanarak, ölçekte ifade edilen faaliyetlere katılım düzeyinizi her bir madde için lütfen belirtiniz.

\begin{tabular}{|c|c|c|c|c|c|}
\hline Nanoteknoloji deneyiminiz (ile etkileşiminiz) nedir? & 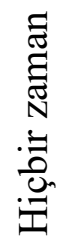 & 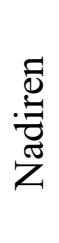 & 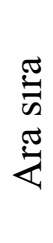 & $\begin{array}{l}\frac{y}{\omega} \\
\frac{y}{0} \\
ن\end{array}$ & 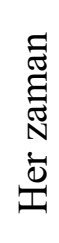 \\
\hline \multicolumn{6}{|l|}{ Nanoteknoloji terimini duydum. } \\
\hline \multicolumn{6}{|l|}{ Nanoteknoloji hakkında bir şeyler okudum. } \\
\hline \multicolumn{6}{|l|}{ Nanoteknoloji hakkında bir program izledim. } \\
\hline \multicolumn{6}{|l|}{$\begin{array}{l}\text { Sınıfta bir (veya daha fazla) öğretmen/öğretim } \\
\text { elemanının nanoteknoloji hakkındaki konuşmalarını } \\
\text { dinledim. }\end{array}$} \\
\hline \multicolumn{6}{|l|}{$\begin{array}{l}\text { Nanoteknoloji konusunun işlendiği bir etkinliğe } \\
\text { katıldım (laboratuvar çalışması, proje, seminer, } \\
\text { konferans). }\end{array}$} \\
\hline Nanoteknoloji hakkında bir ders aldım. & & & & & \\
\hline
\end{tabular}


C. Aşağıdaki sorular Nanobilim ve Nanoteknoloji hakkında bilgi düzeyinizi belirlemek amacıyla hazırlanmıştır. Nanobilim ve Nanoteknoloji konusu son yıllarda oldukça güncel olmasına rağmen bu kavramlar ve uygulama alanları olarak oldukça yeni olduğundan soruları eksiksiz ve doğru olarak yanıtlamanız beklenmemektedir. Amaç sizleri test etmek ve değerlendirmek değildir. Amacımız sizlerin Nanoteknoloji hakkında varsa bilgi düzeyinizi belirlemektir. Araştırmada sizlerin kimliklerini belirleyecek ifadelere ve sorulara yer verilmemiştir. Katılımınız ve sorulara verdiğiniz samimi yanıtlardan dolayı teşekkür ederiz.

1. Nanometre, metrenin birine denk gelir.

2. Nanometre boyutunda nesnelere örnek olarak verilebilir.

3. Nanoölçek boyutunda nesnelerin ölçülmesinde kullanılan araçlardan biri dir.

4. Nanoteknolojinin birçok uygulama alanı bulunmaktadır. Ayrıca farklı alanlarda kullanılan Nanoteknoloji yöntemleri ile geliştirilen malzemeler ve araçlar bulunmaktadır. Aşağıya bildiğiniz Nanoteknolojinin uygulama alanları ile bu alanda geliştirilen malzeme veya araç adı yazabilir misiniz?

$\underline{\text { Uygulama alan1 }}$

Geliștirilen malzeme veya araç
a.
b.
c.
d.
e.

5. Nanoteknoloji uygulamaları tarafından geliştirilerek gelecekte insanları doğrudan veya dolaylı olarak etkileyecek bir malzeme veya araca örnek verir misiniz? 